\title{
Investigating the Rainforest Canopy Phenology Variation and Productivity Responses to Drought by Using Digital Camera Images
}

\author{
Sai Tay Zar Myo ${ }^{1,3,4}$, Yiping Zhang ${ }^{1,2}$, Qinghai Song ${ }^{1,2}$, Xuehai Fei ${ }^{5}$, Donghai Yang ${ }^{1,6}$, Zayar Phyo ${ }^{1,3,4}$ \\ ${ }^{1}$ CAS Key Laboratory of Tropical Forest Ecology, Xishuangbanna Tropical Botanical Garden, Chinese Academy of Sciences, \\ Xishuangbanna 666303, PR China \\ ${ }^{2}$ Center of Plant Ecology, Core Botanical Gardens, Chinese Academy of Sciences, Xishuangbanna \\ 666303, PR China \\ ${ }^{3}$ University of Chinese Academy of Sciences, Beijing, 100049, PR China \\ ${ }^{4}$ Myanma Timber Enterprise, Ministry of Natural Resources and Environmental Conservation, Yangon, Myanmar \\ ${ }^{5}$ College of Resources and Environmental Engineering, Guizhou University, Guiyang, Guizhou, PR China \\ ${ }^{6}$ Xishuangbanna Station for Tropical Rainforest Ecosystem Studies, Chinese Academy of Sciences \\ Xishuangbanna 666303, PR China
}

\begin{abstract}
Among the natural disturbances, drought may cause significant change in forest ecosystems by shifting phenology and productivity. Digital cameras have been used in phenological observations for their high accuracy and the colour index values (digital-number of red, green and blue) derived from long-term continuous digital camera imagery are useful as proxies for investigating a forest canopy's response to drought. Here, we examine the interaction between colour indices (the strength of red $\left(S_{\text {red }}\right)$, the strength of green $\left(S_{\text {green }}\right)$, green excess index $(\mathrm{GEI})$ ), productivity (gross primary productivity (GPP)) and drought (standardised precipitation evapotranspiration index (SPEI)) and climatic factors. We use forest canopy images derived from a digital camera and flux tower-based productivity from 2010 to 2016 to show the rainforest's responses to drought in phenology and productivity. The SPEI indicated the occurrence of drought condition in 2014. The lowest values of the SPEI (-0.403 mmday $\left.{ }^{1}\right)$, and total precipitation $\left(1062 \mathrm{mmyr}^{-1}\right)$, and the highest values of average air temperature $\left(21.3^{\circ} \mathrm{C}\right)$, potential evapotranspiration $\left(3.31 \mathrm{mmday}^{-1}\right)$ and rain use efficiency $\left(2.26 \mathrm{gCL}^{-1}\right)$ were found in 2014. Leaf color variation period (CVP) become longer with an advance in foliage green-up after drought. The peak GEI values were found at the end of the CVPs. The GPP and the $S_{\text {green }}$ had positive and the $S_{\text {red }}$ had negative relationship with drought index. The GPP dropped during the drought and bounced back after the drought due to a longer leaf CVP. The $S_{\text {green }}$ and GEI were significantly $(p<0.05)$ related to GPP during the drought. During the CVP of the drought, the $S_{\text {green }}$ and GEI were significantly correlated $(p<0.05)$ with total $P$, PET and average Ta, meanwhile, there was only a significant relationship $(\mathrm{p}<0.05)$ between the GPP with PET and avg Ta. Among the variables, the GPP was more significant $(\mathrm{p}<0.001)$ with avg Ta. There was also a relationship between the colour indices and GPP with climatic factors on a yearly time series. Our results indicate an understanding of the phenology and productivity response of rainforests to drought, which might be useful for ecologists when predicting the effects of future climatic change on rainforest phenology and productivity.
\end{abstract}

KEYWORDS: Colour indices; Digital camera images; Drought; Gross primary productivity (GPP); leaf colour variation period (CVP); Standardised Precipitation Evapotranspiration Index (SPEI)

\section{INTRODUCTION}

Terrestrial ecosystems can face natural disasters including extreme fire, windstorms, flooding, frosts, precipitation, heatwaves, droughts and other climatic extremes. Of these, drought is a major disturbance in nature and has effects in forest ecosystem functions, services and biodiversity (Caudullo and Barredo, 2019). Droughts have the strongest and most widespread effects on terrestrial ecosystems and carbon cycling. In the next 30 to 90 years, most areas will face droughts due to decreased precipitation and increased evaporation (Dai, 2013). The impact of climate change, precipitation, temperature (Cao et al., 2018; Dahlin et al., 2017) and drought (A. Zhao et al., 2018) cause changes to vegetation dynamics (Zhang et al., 2017), phenological variations (Čehulić et al., 2019; Yu et al., 2015) and declined gross primary production (GPP) (Ciais et al., 2005). Drought affects the 


\section{International Journal of Current Science Research and Review}

ISSN: 2581-8341

Volume 04 Issue 10 October 2021

DOI: 10.47191/ijcsrr/V4-i10-20, Impact Factor: 5.825

IJCSRR @ 2021

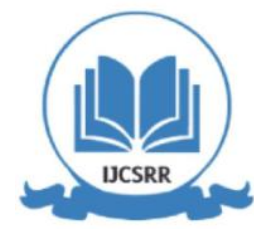

Www.ijesrr.org

development of roots and shoots (Zahir et al., 2014) and biomass accumulation (Liu et al., 2020), and also causes canopy chan ges (Saatchi et al., 2013), widespread crown defoliation in trees (Pollastrini et al., 2019), forest fecundity(Bogdziewicz et al., 2020) andchanges to mortality rate (Caudullo and Barredo, 2019; Fensham et al., 2019; Stovall et al., 2019), productivity (Zhao et al., 2019) and yield (Onyewotu et al., 1998). The response of plant phenology to temperature variations also depend on the climatic regions (Prevéy et al., 2017). The conversion of rainforests into rubber plantations caused the deterioration of biodiversity and ecosystem services in southwest China ( $\mathrm{Li}$ et al., 2007). Thus, the condition of rainforest ecosystem variation is critical for this area.

The pattern of plant phenology in response to climate change is an easily observed trait that varies among the species and depends on the environmental factors. The changes of the plant canopy in response to drought causes leaf withering and senescence. Variations in environmental conditions enhance changes in the terrestrial ecosystem and are especially effective on agriculture (Salinger et al., 2000). Plants' physiological responses to drought can happen quickly, but changes to the canopy take a long time (Zhang et al., 2016). Most researchers have studied reductions in species' richness and cover (Copeland et al., 2016) and tree-ring responses to the effects of drought (Li et al., 2020), but some focus on the canopy phenology variation and productivity responses to the drought. Digital camera images are widely used as phenological indicators to assess the forest canopy response to climate change in the tropics. Data can also be collected hourly, daily or over several years from specific or regional areas for conservation (Alberton et al., 2017). The colour indices obtained from images can be used to analyse the GPP (WestergaardNielsen et al., 2013) and phenological variations of the forest cover (Nagai et al., 2016), and to investigate the effects of drought on tree mortality (Anderson et al., 2010). Thus, the rainforest canopy phenology variation and productivity responses to drought need to be investigated.

Droughts particularly result from reductions in annual precipitation and related to rain use efficiency (RUE) that affected by phenological variations (Huang et al., 2018). Rain use efficiency is the amount of rainfall required for plants, and this can also be used as an indicator of ecosystem functionality (Y. Zhao et al., 2018). Researchers have tested the impact of experimental drought on mortality rate (Ogaya et al., 2020) and growth (Liu et al., 2020). There are several drought indices; temperature variations derived the Palmer drought severity index (Palmer, 1965), and precipitation variations derived the standardised precipitation index (McKee et al., 1993), which lack the multiscalar character needed for assessing drought. Vicente-Serrano et al. (2010) proposed a new simple multiscalar drought index, the standardised precipitation evapotranspiration index (SPEI), which combines the effects of precipitation and temperature data. Here, we assess the impact of meteorological drought on phenology and productivity variations using the standardised precipitation evapotranspiration index (SPEI).

The previous study of the canopy temperature depression in the rainforest pointed out that there was a drought effect (Myo et al., 2019). Drought can have an effect on the productivity of the rainforest and the responses of canopy phenology to climate change might also be variable. Shifts in tree phenology in response to drought can also influence the productivity. The interactions of climate, leaf colour variation period (CVP), and gross primary productivity (GPP) is critical to quantify the changing dynamics of phenology in the rainforest. The drought effects on rainforest phenology and productivity have been no study dealing with the climate change effects on tree canopy using digital camera images in our study area. Based on the SPEI and colour indices (the strength of green $-S_{\text {green }}$, the strength of red $-S_{\text {red }}$ and green excess index - GEI), we investigate the effects of drought on phenology variations and the GPP in the rainforest. The objectives of the study are: (1) to examine the annual variations of climatic factors, phenology and the GPP based on digital camera images and flux observations; (2) to assess the effects of drought on the phenology variations and the GPP; and (3) to examine the relationships between colour indices, the GPP and the SPEI.

\section{MATERIALS AND METHODS}

\subsection{Study site}

The rainforest study area, the permanent research plot in the Menglun Nature Reserve, is situated at $21^{\circ} 55^{\prime} 39^{\prime \prime} \mathrm{N}, 101^{\circ} 15^{\prime} 55^{\prime \prime} \mathrm{E}$, $750 \mathrm{~m}$ above sea level, in the Yuannan Province, southwestern China (Fig. 1). The area has a monsoon climate with long summer and no winter. It consists of different ages of mixed stands with trees of different heights and structures. The rainforest is dominated by the deciduous species of Pometia tomentosa, Terminalia myriocarpa, Gironniera subaequalis and Garuga floribunda and can exceed $40 \mathrm{~m}$ in height. The soil type is lateritic with a pH level between 4.5 and 5.5 . The weather is dry and hot, with a mean annual temperature of $21.4{ }^{\circ} \mathrm{C}$ and mean annual precipitation of $1415 \mathrm{~mm}$. The majority of the total precipitation 


\section{International Journal of Current Science Research and Review}

ISSN: 2581-8341

Volume 04 Issue 10 October 2021

DOI: 10.47191/ijesrr/V4-i10-20, Impact Factor: 5.825

IJCSRR@ 2021

WwW.ijesrr.org

(80.00) occurs during the rainy season from May to October, and the dry season is from November to April. The observation period lasted from 2010 to 2016.

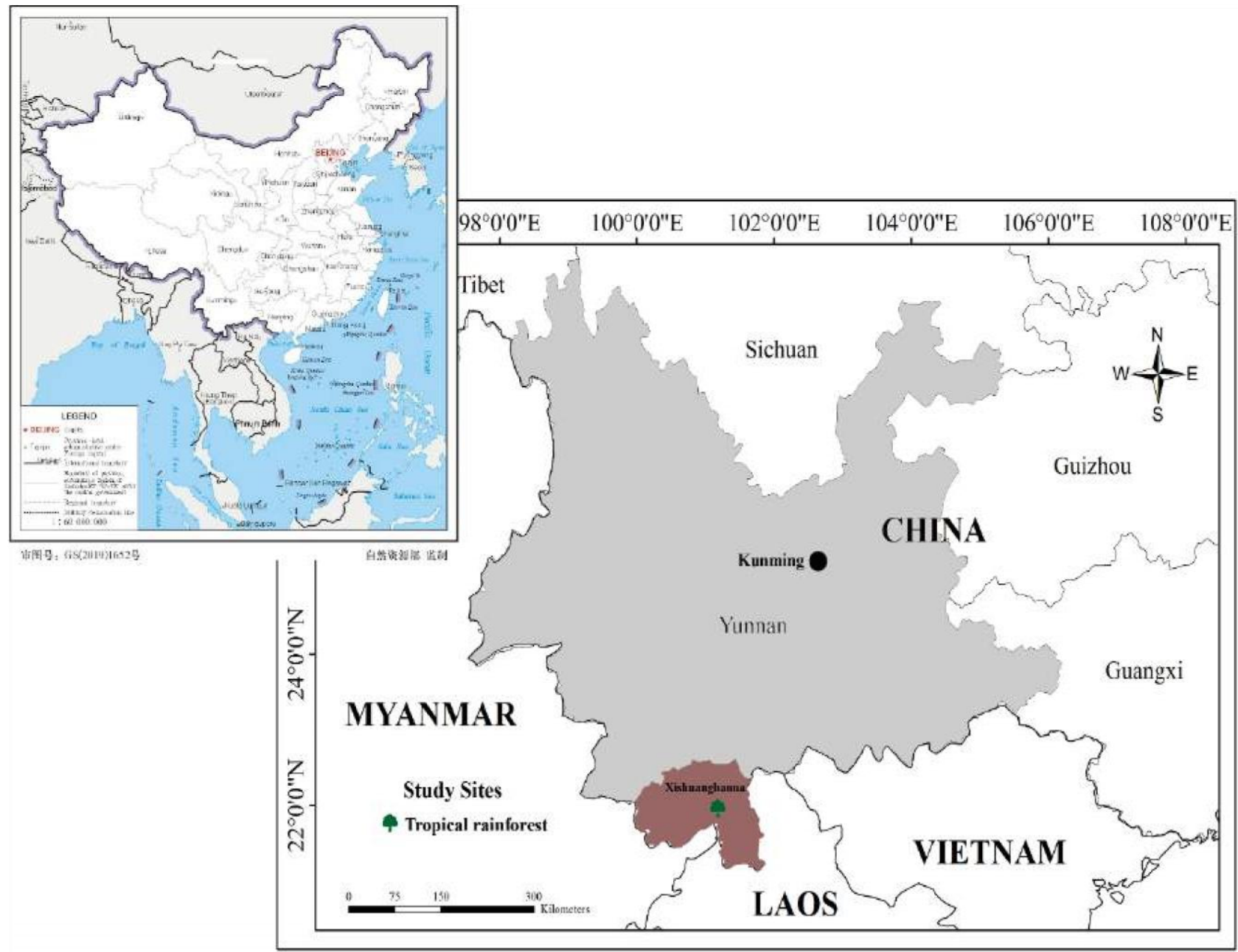

Fig.1. Location of the study site

\subsection{Digital camera setting and processing}

At a height of $36 \mathrm{~m}$ above the ground, a digital camera (Ricoh Caplio R4) was installed on a 72m-high flux tower. The camera was covered with a weatherproof box and fixed in a southeast facing direction. The digital camera was adjusted with a 20-degree angle position to cover the study area. The camera was set with the time interval of 1 photo per every 1 hour. Hourly digital images were taken and stored as JPEG format images. The automated white balance adjustment setting was used to avoid undesirable colour bands. The images taken around noon were best for analysing and reducing the effects of the illumination angle (Ahrends et al., 2008). To get strong basic digital colour index values, we selected the best image per day and automatically excluding images taken in unfavourable weather conditions or at night. Due to a machine error, the digital camera images for the periods of January to March 2015 and September to December 2016 were missing. 


\section{International Journal of Current Science Research and Review}

ISSN: 2581-8341

Volume 04 Issue 10 October 2021

DOI: 10.47191/ijcsrr/V4-i10-20, Impact Factor: 5.825

IJCSRR@ 2021

WwW.ijesrr.org

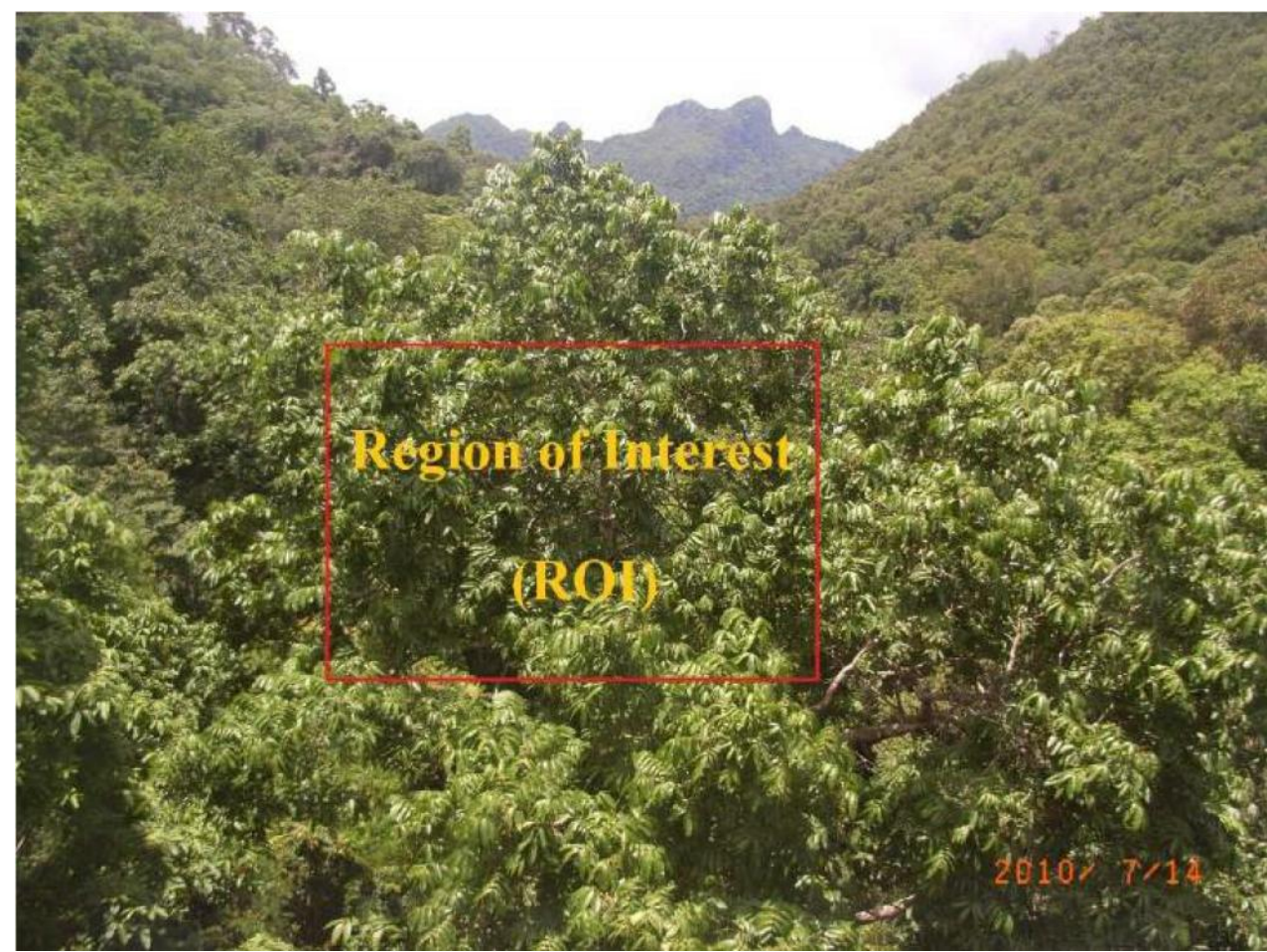

Fig.2. Region of interest (ROI) of the rainforest image that was taken with a digital camera.

Among all the images taken throughout the study period, the most representative one was chosen, selected the prominent tree and set the region of interest (ROI) (Fig. 2). Here, we aim to evaluate the leaf colour variation period (CVP) that is defined as the time interval between the fractions of red and green colour index diverged in the spring and converged in the fall each year.

We used R software (R Core Team, 2017) to extract the digital number of the red (R), green (G) and blue (B) channels of the ROI from the images. To analyse the canopy's phenological variations, the strength of red $\left(\mathrm{S}_{\mathrm{red}}\right)$, the strength of green $\left(\mathrm{S}_{\text {green }}\right)$ and the strength of blue $\left(S_{\text {blue }}\right)$ relative to the total RGB are used (Ahrends et al., 2008). The strength of each RGB colour channel $\left(S_{\text {red }}\right.$, $S_{\text {green }}$ and $S_{\text {blue }}$ ) is calculated as follows (Gillespie et al., 1987):

$$
\begin{aligned}
& S_{\text {red }}=R /(R+G+B) \\
& S_{\text {green }}=G /(R+G+B) \\
& S_{\text {blue }}=B /(R+G+B)
\end{aligned}
$$

where, R, G and B are the brightness levels of the red, green and blue of each colour channel from image files that are influenced by scene illumination and express with the digital number. The strength of red $\left(S_{\text {red }}\right)$, the strength of green $\left(S_{\text {green }}\right)$ and the strength of blue $\left(\mathrm{S}_{\text {blue }}\right)$ are chromatic coordinates sense that can be restrained the scene illumination.

To express the canopy's greenness, the green excess index (GEI) (Woebbecke et al., 1995) is widely used, which is calculated as follow:

$$
\boldsymbol{G E I}=(\boldsymbol{G}-\boldsymbol{R})+(\boldsymbol{G}-\boldsymbol{B})=\mathbf{2} \boldsymbol{G}-(\boldsymbol{R}+\boldsymbol{B})
$$

\subsection{Eddy flux data and meteorological measurement}

The meteorological instruments; a temperature sensor (HMP45C®, Vaisala, Helsinki, Finland) for the air temperature was fixed at a height of $36 \mathrm{~m}$ above the ground on the 72-m-high flux tower, a rain gauge (Rain Gauge 52203®, Young Co., Traverse City, MI, USA) for precipitation was fixed on the top of the flux tower, and a radiation sensor (CNR-1/CM11®, Kipp \& Zonen, Delft, Netherlands) for downward and upward, short- and long-wave radiation was fixed at a height of $41 \mathrm{~m}$ above the ground on a 3-m horizontal pole from the flux tower. The time interval was set to every 30 minutes for collection of the meteorological data. A CR1000 datalogger (Campbell Scientific, Logan, UT, USA) was used to collect the data. The SPEI for drought assessment was 


\section{International Journal of Current Science Research and Review}

ISSN: 2581-8341

Volume 04 Issue 10 October 2021

DOI: 10.47191/ijcsrr/V4-i10-20, Impact Factor: 5.825

the monthly difference between precipitation (P) and potential evapotranspiration (PET), and this was calculated as follows (Vicente-Serrano et al., 2010):

$$
S P E I=P-P E T
$$

The monthly average PET can be calculated with the temperature (T) and solar radiation (Q) as follows (Hargreaves and Samani, 1985):

$$
P E T=0.0023(T+17.8)\left(T_{\max }-T_{\min }\right)^{0.5} Q
$$

where $\mathrm{T}$ is the mean daily temperature, $\mathrm{T}_{\max }$ and $\mathrm{T}_{\min }$ are the monthly maximum and minimum temperatures and $\mathrm{Q}$ is the mean daily incoming shortwave solar radiation respectively. The eddy covariance technique for quantifying exchanges of carbon dioxide and water vapour between the surface of earth and the atmosphere was used and installed a triaxial sonic anemometer (CSAT3, Campbell Scientific Inc., USA) and a high-frequency open-path $\mathrm{CO}_{2} / \mathrm{H}_{2} \mathrm{O}$ infrared gas analyzer (Li-7500, Li-Cor Inc., USA) at a height of $48.8 \mathrm{~m}$ above the ground on the flux tower. Details of the installation system used at this station have been previously published (Fei et al., 2018).

The gross primary productivity (GPP) was used to calculate the difference between ecosystem respiration ( $\left.\mathrm{R}_{\mathrm{eco}}\right)$ and net ecosystem exchange (NEE) as follows (Gilmanov et al., 2007):

$$
\begin{gathered}
G P P=R_{e c o}+(-N E E) \ldots \ldots \ldots \ldots \ldots \ldots \ldots \ldots \ldots \\
R_{e c o}=R_{e c o, r e f} \times e^{E_{0}\left(\frac{1}{T_{r e f}-T_{0}}-\frac{1}{T-T_{0}}\right)}
\end{gathered}
$$

where $\mathrm{R}_{\text {eco,ref }}$ is the reference ecosystem respiration at the reference temperature $\left(\mathrm{T}_{\text {ref }}\right.$; here, $\left.283.15 \mathrm{~K}\right)$, $\mathrm{E}_{0}$ is the fitted parameter, $\mathrm{T}_{0}$ is a constant set to $227.13 \mathrm{~K}$, and $\mathrm{T}$ is the measured soil temperature at $10 \mathrm{~cm}$ in this study.

The NEE consists of the turbulent eddy flux $\left(\mathrm{F}_{\mathrm{c}}\right)$ and the storage flux $\left(\mathrm{F}_{\mathrm{s}}\right)$ as follow (Hollinger et al., 1994):

$$
N E E=F C+F s=\rho \overline{w^{\prime} c^{\prime}}+\frac{\Delta c}{\Delta t} \mathrm{zr}
$$

where Fc represents the turbulent eddy flux transported above the height of the EC system and the atmosphere and Fs indicates the storage flux under the plane of the EC system and the ground surface. A single-point method was applied to measure the Fs at the measurement height (zr) of the fluxes. In addition, $\rho, w$, and c represent the air density, vertical wind velocity, and target scalar concentration, respectively; the primes denote fluctuations from the average, and the overbar signifies the average taken over a given time (30 min in this case). $\Delta \mathrm{c}$ is the variation over a 30 -min period at height $\mathrm{zr}$, $\mathrm{zr}$ is the height of the EC system, and $\Delta \mathrm{t}$ is the time interval (1800 $\mathrm{s}$ in this case).

RUE is the ratio of the GPP and precipitation (P), and this is calculated as follows (Huxman et al., 2004; Lauenroth et al., 2000):

$$
R U E=G P P / P
$$

\subsection{Data analysis}

We examined the interannual dynamics of climatic factors (average air temperature - avg Ta, total precipitation - total $\mathrm{P}$, and PET), drought indices (SPEI), colour indices $\left(S_{\text {red }}, S_{\text {green }}, S_{\text {blue }}\right.$, and GEI) and carbon flux data (GPP). The colour index values were computed with the digital number extracted from the camera images. The linear model was used to analyse the relationship between the colour indices $\left(S_{\text {red }}, S_{\text {green }}\right.$ and GEI) and GPP during the leaf colour variation periods, and the colour indices $\left(S_{\text {red }}\right.$, and $\mathrm{S}_{\text {green }}$ ), GPP and climatic factors throughout the years.

The multiple linear model was used to analyse between the colour indices ( $S_{\text {red }}, S_{\text {green }}$ and GEI), GPP and climatic factors (total P, PET and avg Ta) throughout the years. A significance level $(\mathrm{p}<0.05)$ was considered as statistically significance between the groups. Correlation coefficients between the climatic factors were calculated using Pearson's bivariate correlation. SigmaPlot for Windows (Systat Software, Chicago, Illinois, USA; version 12.5) was used to perform statistical analysis. The pattern of leaf colour variation period (between the fractions ofdiverged and converged of the $S_{\text {red }}$ and $S_{\text {green }}$ ) were detected by analysing the canopy surface images. The data from low-visibility images were removed to avoid uncertainty, and three-day moving windows (Sonnentag et al., 2012; Toomey et al., 2015) were used to reduce the impact of undesirable conditions. 


\section{International Journal of Current Science Research and Review}

ISSN: 2581-8341

Volume 04 Issue 10 October 2021

DOI: 10.47191/ijesrr/V4-i10-20, Impact Factor: 5.825

\section{RESULTS}

3.1. The annual pattern of climatic factors, RUE and the drought index

Fig. 3 shows the annual pattern of the climatic factors (total P, avg Ta and PET), RUE and the drought index (SPEI) from 2010 to 2016. The pattern of total P $(1062 \mathrm{~mm})$ and SPEI $\left(-0.40\right.$ mmday $\left.^{-1}\right)$ of the year 2014 were lower than the others evidently. Meanwhile, the avg Ta, PET and RUE were also higher than the others. According to the value of the SPEI $\left(-0.403 \mathrm{mmday}^{-1}\right)$, the year of 2014 was indicating the occurrence of the drought effect. During the drought period, total precipitation (1062 $\left.\mathrm{mmyr}^{-1}\right) \mathrm{was}^{-1}$ the lowest and avg Ta (21.25 CC), PET (3.31 mmday $\left.{ }^{-1}\right)$ and RUE $\left(2.26 \mathrm{gCL}^{-1}\right)$ were the highest throughout the study period (Fig. $3)$.

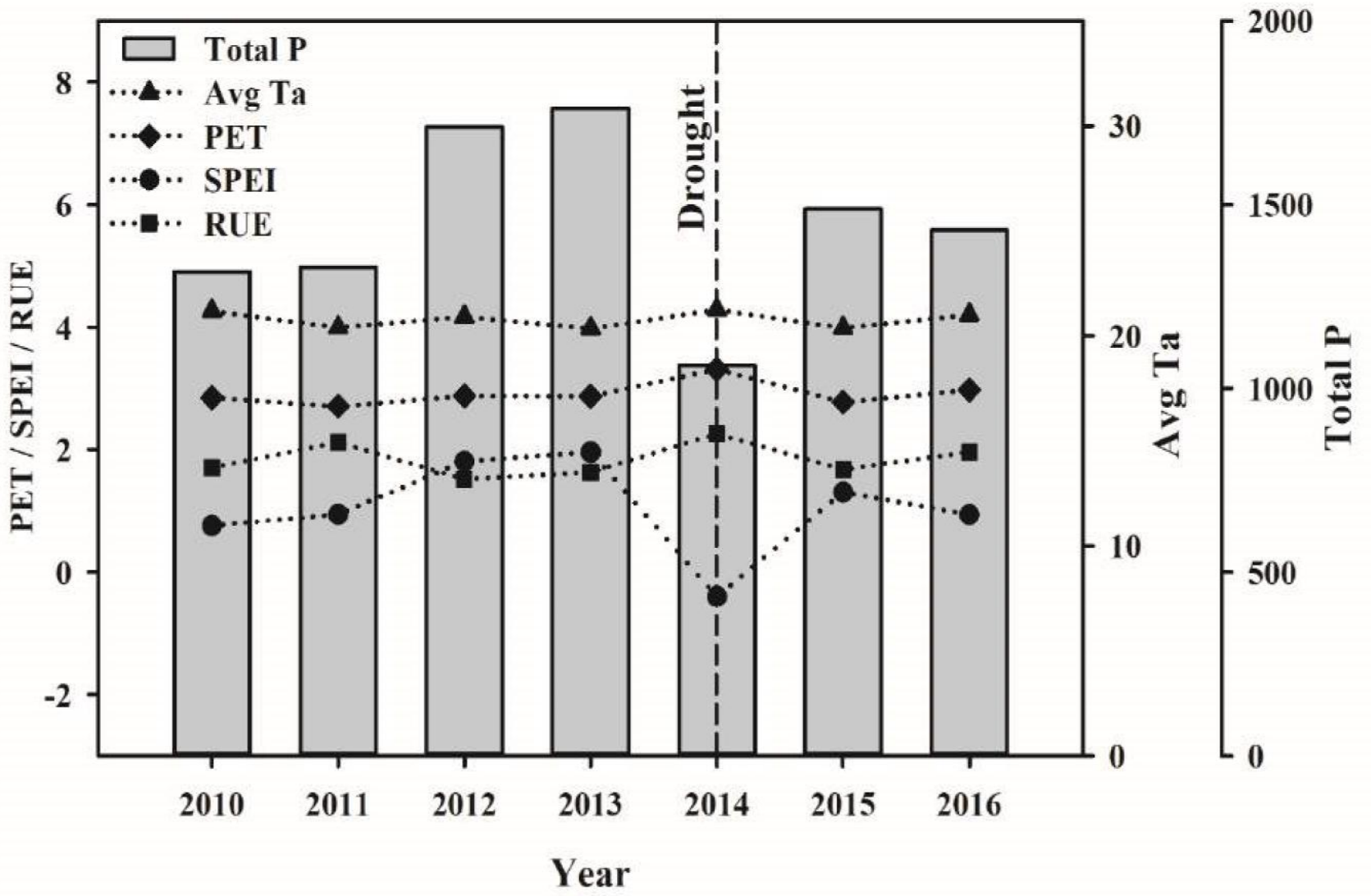

Fig.3. Annual variations in total precipitation (Total P), average air temperature (Avg Ta), potential evapotranspiration (PET), standardised precipitation evapotranspiration index (SPEI) and rain use efficiency (RUE). Vertical dashed line indicates the drought period determined from the SPEI.

\subsection{The pattern of phenological variations}

The annual variation of the colour indices $\left(S_{\text {red }}, S_{\text {green }}, S_{\text {blue }}\right.$ and GEI), GPP and climatic factors (total P, avg Ta and PET) from 2010 to 2016 are shown in Fig. 4. The phenological events of the end of leaf fall and the start of leaf emergence were found in the same period from 2010 to 2014 . However, the beginning of leaf emergence was DOY +9 days earlier than the end of the leaf fall in the year of 2015 and 2016 after the drought effect (Fig. 4). Meanwhile, the pattern of GPP was shown as decreasing during the drought period of 2014, and increasing after the drought periods of 2015 and 2016 in (Fig. 4 and 7). 
ISSN: 2581-8341

Volume 04 Issue 10 October 2021

DOI: 10.47191/ijesrr/V4-i10-20, Impact Factor: 5.825

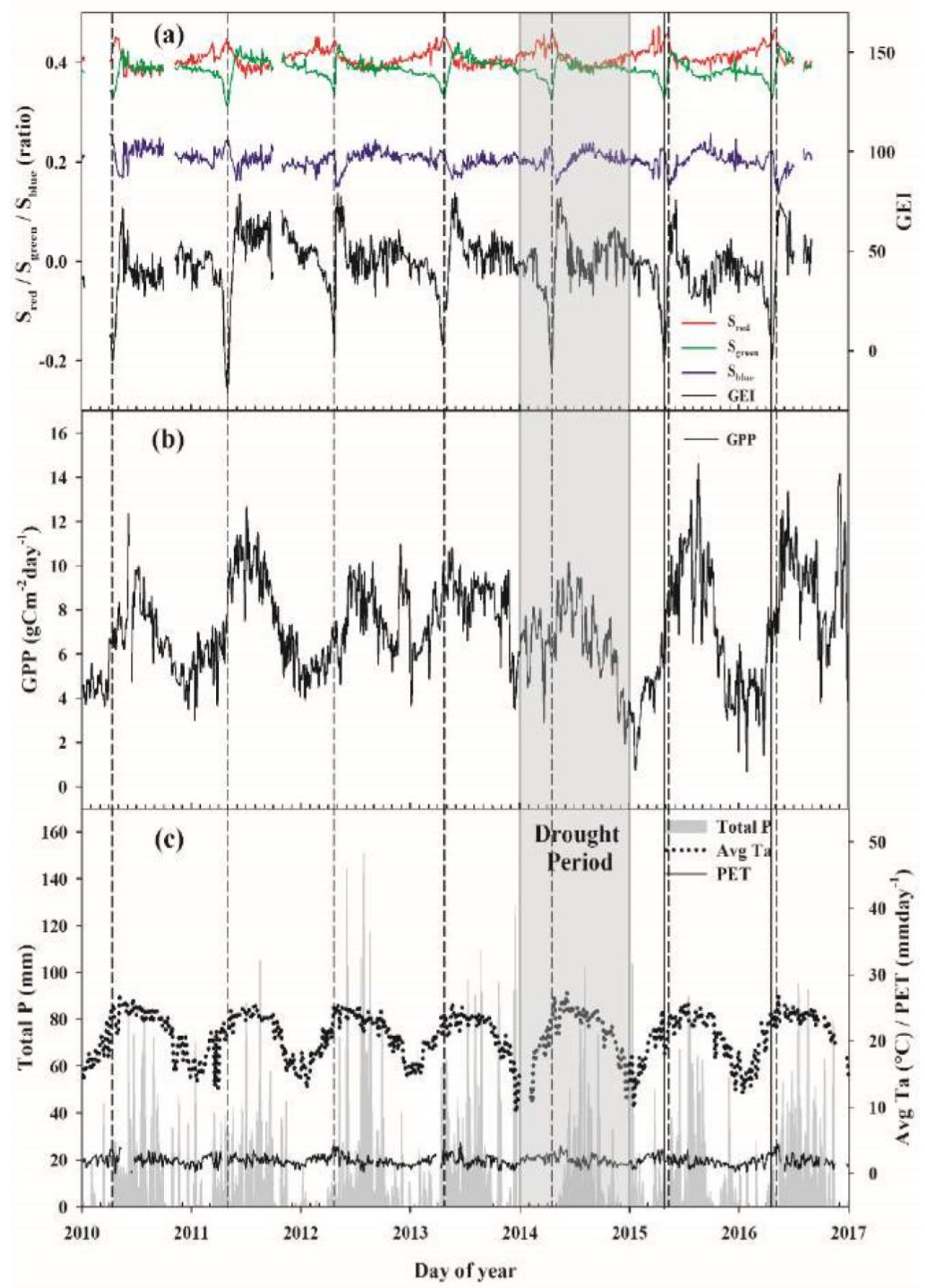

Fig.4. The pattern of the annual dynamics of (a) the colour indices (strength of red $\left(S_{\text {red }}\right)$, strength of green $\left(S_{\text {green }}\right)$, strength of blue $\left(S_{\text {blue }}\right)$ and green excess index $(\mathrm{GEI})$ ), (b) the gross primary productivity (GPP) and (c) the climatic factors (total precipitation (Total P), average air temperature (Avg Ta) and PET) from 2010 to 2016. The vertical dashed lines represent the phenological events (start of leaf emergence and end of leaf fall); the vertical black lines represent the advanced phenological events (advanced in leaf emergence); the grey rectangles indicate the drought periods.

The average leaf CVP was 241 days during the 7 years. After the occurrence of the drought effect, the leaf CVP was longer than in the pre-drought period (Fig. 5). The start of the increase of the $S_{\text {red }}$ and the decrease of the $S_{\text {green }}$ in the periods of 2014 to 2015 and 
ISSN: 2581-8341

Volume 04 Issue 10 October 2021

DOI: 10.47191/ijcsrr/V4-i10-20, Impact Factor: 5.825

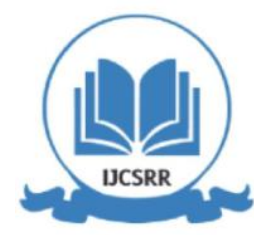

Www.ijesrr.org

2015 to 2016 was +144 days earlier than the previous, but the end of the process was nearly similar throughout the study period

(Fig. 5). Meanwhile the peak GEI values were found at the end of CVPs throughout the years (Fig. 5).

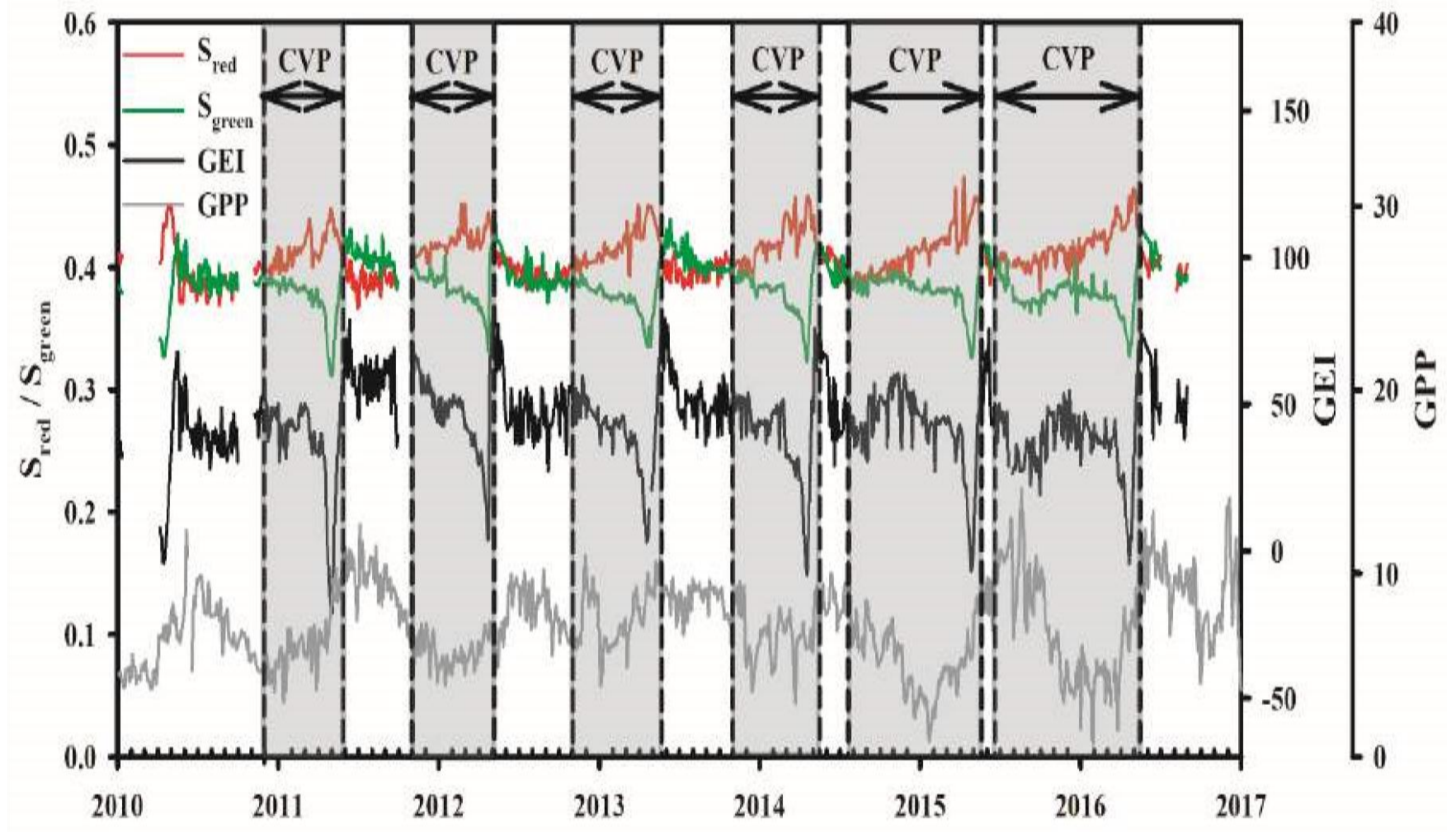

Day of year

Fig.5. The pattern of leaf colour variation period (CVP) (the time interval between the fractions of red and green colour index diverged in the spring and converged in the fall each year), as indicated in the figure with grey rectangles, green excess index (GEI) and productivity

(GPP).

\subsection{Relationship between the colour indices, GPP and climatic factors}

The GPP had a positive relationship with the $S_{\text {red }}$ and negative relationship with the $S_{\text {green }}$ during the CVPs from 2010 to 2013 (Fig. 6). However, the inverse relationship was found in the CVPs from 2013 to 2016 (Fig. 6). Meanwhile, the GPP had a negative relationship with GEI during the CVPs throughout the years, except from 2012 to 2014 (Fig. 6). Significant relationships (p $<0.05$ ) between the GPP and the $S_{\text {green }}$ were found during and after the drought of the CVPs of 2013 to 2014 and 2014 to 2015 , while significant relationships $(\mathrm{p}<0.05)$ between the GPP and $\mathrm{S}_{\text {red }}$ were found after the drought of the CVPs of 2014 to 2015 and 2015 to 2016. Meanwhile, significant relationships $(\mathrm{p}<0.01)$ between the GPP and GEI was only found during the drought of the CVP of 2013 to 2014 (Fig. 6). 


\section{International Journal of Current Science Research and Review}

ISSN: 2581-8341

Volume 04 Issue 10 October 2021

DOI: 10.47191/ijcsrr/V4-i10-20, Impact Factor: 5.825

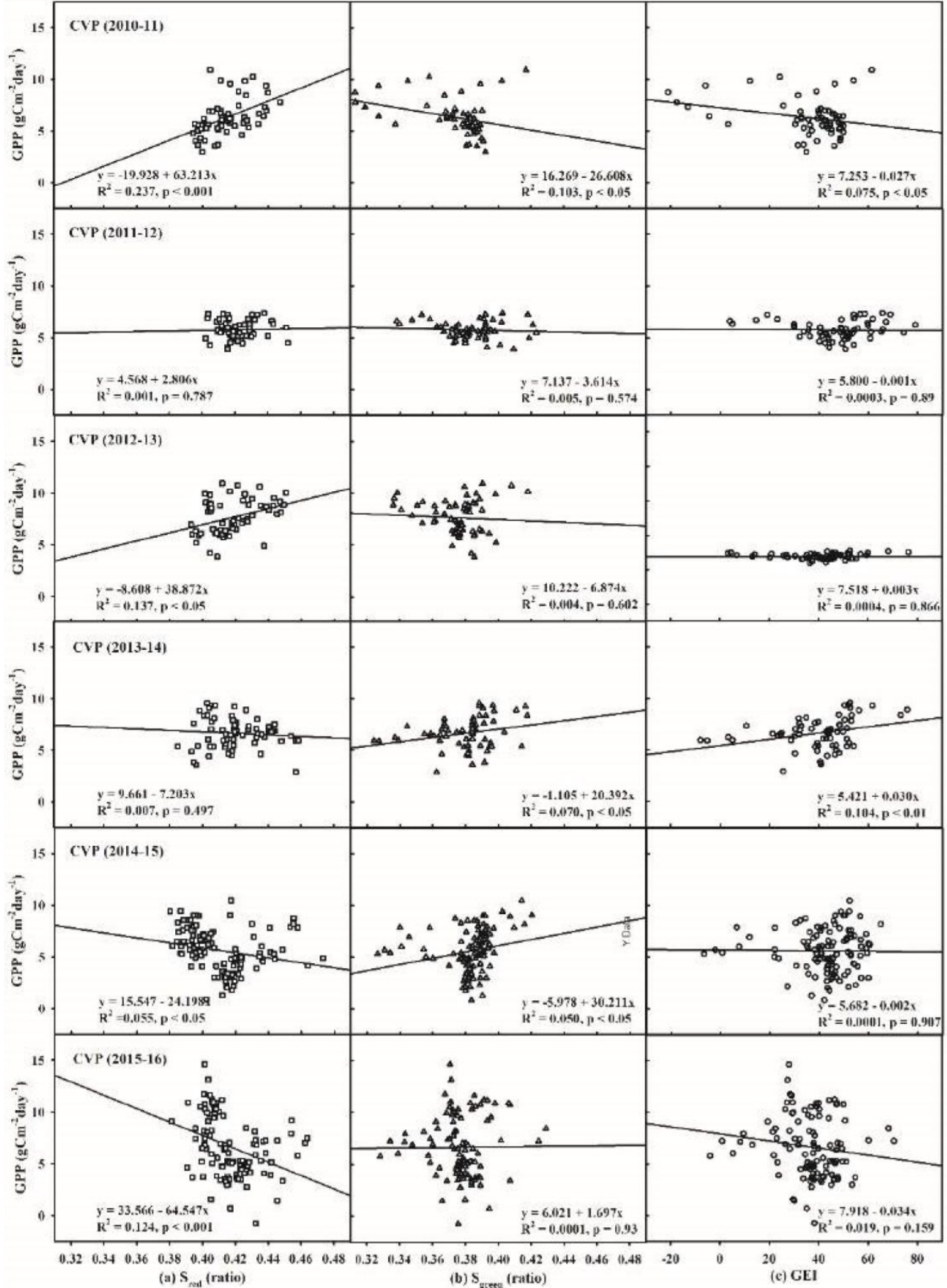

Fig.6. Simple linear regression between the GPP and colour indices during the leaf colour variation periods (CVPs); (a) $\mathrm{S}_{\text {red }}$, (b) $\mathrm{S}_{\text {green }}$ and (c)GEI.

The multiple linear relationship between the colour indices $\left(\mathrm{S}_{\mathrm{red}}, \mathrm{S}_{\text {green }}\right.$ and GEI) and GPP with climatic factors (total P, PET and avg Ta) are shown in Table 1 . The $S_{\text {red }}, S_{\text {green }}$ and GPP were correlated $(p<0.05)$ with Total P, PET and avg Ta throughout the CVP of the years, meanwhile, there was also a relationship between the GEI with Total P, PET and avg Ta on before and during the drought periods of the CVPs, but not throughout all periods (Table 1). 
ISSN: 2581-8341

Volume 04 Issue 10 October 2021

DOI: 10.47191/ijesrr/V4-i10-20, Impact Factor: 5.825

Table 1. The coefficients of determination $\left(\mathrm{R}^{2}\right)$ and probability values (p) from multiple linear regression between the colour indices: the strength of red $\left(S_{\text {red }}\right)$, the strength of green $\left(S_{\text {green }}\right)$, green excess index (GEI) and productivity (GPP) with the climatic factors of total precipitation (total P), PET and average air temperature (avg Ta) in the leaf colour variation periods (CVPs) from 2010 to 2016.

\begin{tabular}{|c|c|c|c|c|c|c|c|c|}
\hline \multirow{2}{*}{ CVP } & \multicolumn{2}{|c|}{$S_{\text {red }}$} & \multicolumn{2}{|c|}{$S_{\text {green }}$} & \multicolumn{2}{|c|}{ GEI } & \multicolumn{2}{|l|}{ GPP } \\
\hline & $\mathbf{R}^{2}$ & $\mathbf{p}$ & $\mathbf{R}^{2}$ & p & $\mathbf{R}^{2}$ & $\mathbf{p}$ & $\mathbf{R}^{2}$ & $\mathbf{p}$ \\
\hline $2010-11$ & 0.461 & $<0.001$ & 0.320 & $<0.05$ & 0.376 & $<0.01$ & 0.594 & $<0.001$ \\
\hline 2011-12 & 0.308 & $<0.01$ & 0.241 & $<0.05$ & 0.163 & 0.113 & 0.210 & $<0.05$ \\
\hline $2012-13$ & 0.556 & $<0.001$ & 0.305 & $<0.01$ & 0.285 & $<0.01$ & 0.379 & $<0.001$ \\
\hline 2013-14 & 0.585 & $<0.001$ & 0.440 & $<0.001$ & 0.497 & $<0.001$ & 0.298 & $<0.01$ \\
\hline $2014-15$ & 0.342 & $<0.001$ & 0.186 & $<0.01$ & 0.065 & 0.313 & 0.684 & $<0.001$ \\
\hline $2015-16$ & 0.434 & $<0.001$ & 0.159 & $<0.01$ & 0.064 & 0.345 & 0.616 & $<0.001$ \\
\hline
\end{tabular}

During the CVP of the drought period of the year 2013-14, the $\mathrm{S}_{\text {green }}$ and GEI were significant correlated ( $\left.\mathrm{p}<0.05\right)$ with Total $\mathrm{P}$, PET and avg Ta, meanwhile, there was only a significant correlated relationship $(\mathrm{p}<0.05)$ between the GPP with PET and avg Ta on drought period (Table

2).

Table 2. The coefficients (coeff) and probability values (p) from multiple linear regression between the color indices: the strength of red $\left(\mathrm{S}_{\text {red }}\right)$, the strength of green $\left(\mathrm{S}_{\text {green }}\right)$, green excess index (GEI) and productivity (GPP) with the climatic factors of total precipitation (total P), PET and average air temperature (avg Ta) in the leaf color variation periods $294 \quad$ (CVPs) from 2010 to 2016.

\begin{tabular}{|c|c|c|c|c|c|c|c|c|c|c|c|c|c|}
\hline \multirow{2}{*}{$\begin{array}{l}\text { Colour } \\
\text { indices/ } \\
\text { Productivity }\end{array}$} & \multirow{2}{*}{ Variables } & \multicolumn{2}{|c|}{$2010-11$} & \multicolumn{2}{|c|}{$2011-12$} & \multicolumn{2}{|c|}{$2012-13$} & \multicolumn{2}{|c|}{$2013-14$} & \multicolumn{2}{|l|}{$2014-15$} & \multicolumn{2}{|c|}{$2015-16$} \\
\hline & & Coeff & $\mathbf{p}$ & Coeff & $\mathbf{p}$ & Coeff & $\mathbf{p}$ & Coeff & $\mathbf{p}$ & Coeff & $\mathbf{p}$ & Coeff & $\mathbf{p}$ \\
\hline \multirow{3}{*}{ Sred } & Total P & o.004 & $<0.01$ & -0.002 & 0.202 & -0.001 & 0.456 & $\begin{array}{l}- \\
0.004\end{array}$ & 0.109 & 0.001 & $<0.05$ & 0.0004 & 0.581 \\
\hline & Avg Ta & 0.001 & 0.532 & 0.0001 & 0.449 & -0.0001 & 0.939 & 0.003 & 0.093 & -0.001 & 0.622 & 0.001 & 0.152 \\
\hline & $\begin{array}{l}\text { Total } \\
\text { P*PET }\end{array}$ & 0.002 & 0.065 & -0.0008 & 0.42 & -0.0002 & 0.301 & 0.005 & 0.123 & 0.0001 & 0.787 & 0.00001 & 0.933 \\
\hline
\end{tabular}


International Journal of Current Science Research and Review

ISSN: 2581-8341

Volume 04 Issue 10 October 2021

DOI: 10.47191/ijesrr/V4-i10-20, Impact Factor: 5.825

IJCSRR@ 2021

www.ijesrr.org

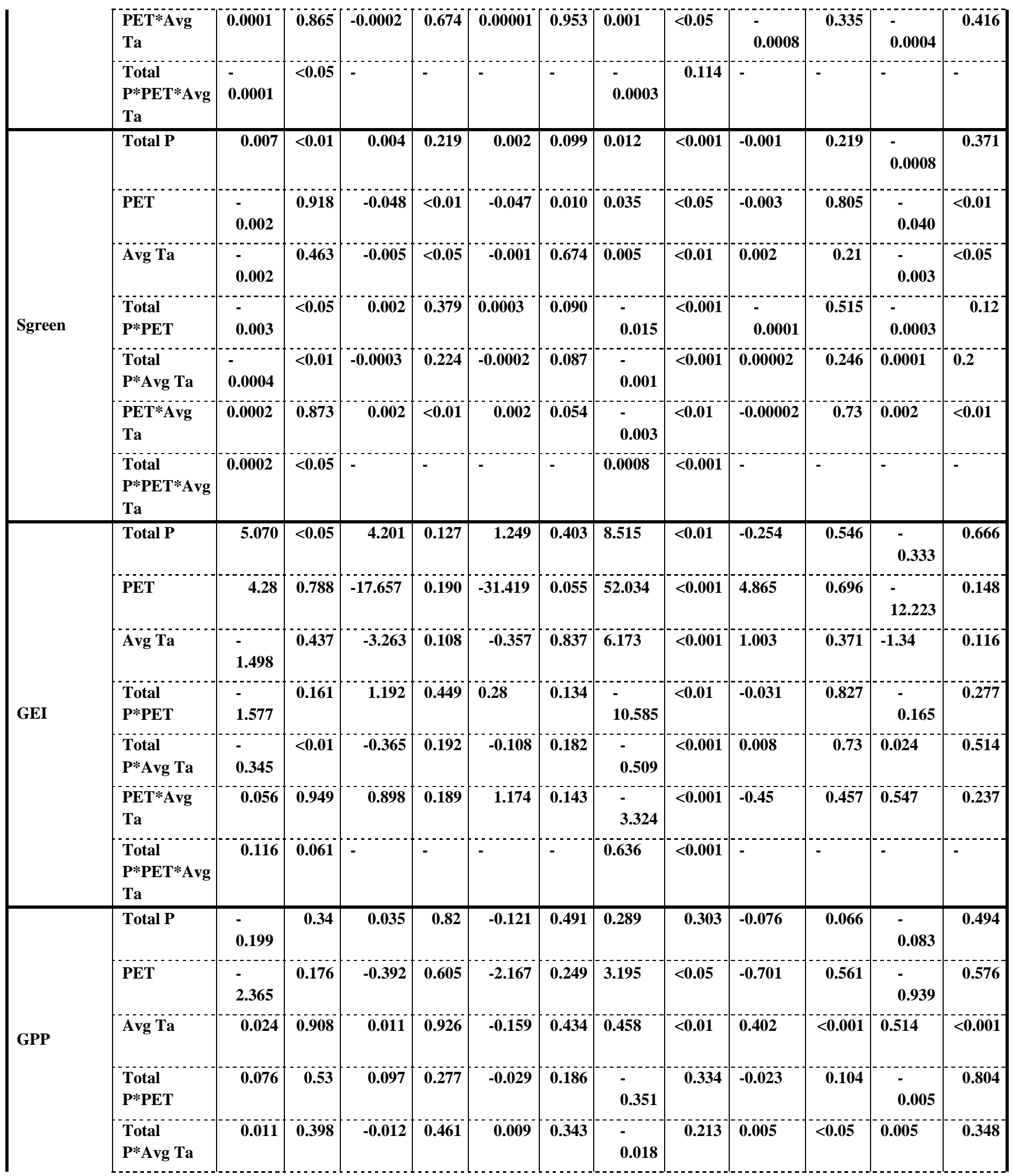




\section{International Journal of Current Science Research and Review}

ISSN: 2581-8341

Volume 04 Issue 10 October 2021

DOI: 10.47191/ijesrr/V4-i10-20, Impact Factor: 5.825

IJCSRR@ 2021

WwW.ijesrr.org

\begin{tabular}{|c|c|c|c|c|c|c|c|c|c|c|c|c|}
\hline $\begin{array}{l}\text { PET*Āg } \\
\text { Ta }\end{array}$ & 0.156 & 0.109 & 0.026 & 0.494 & 0.156 & 0.095 & 0.175 & $<0.05$ & 0.029 & 0.626 & 0.027 & 0.711 \\
\hline $\begin{array}{l}\text { Total } \\
\text { P*PET*Avg } \\
\text { Ta }\end{array}$ & 0.004 & 0.516 & 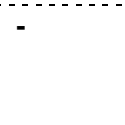 & $\because$ & 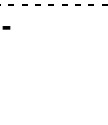 & - & 0.021 & 0.283 & - & 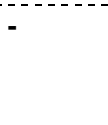 & - & - \\
\hline
\end{tabular}

3.4. Annual trends in colour indices, GPP and drought index

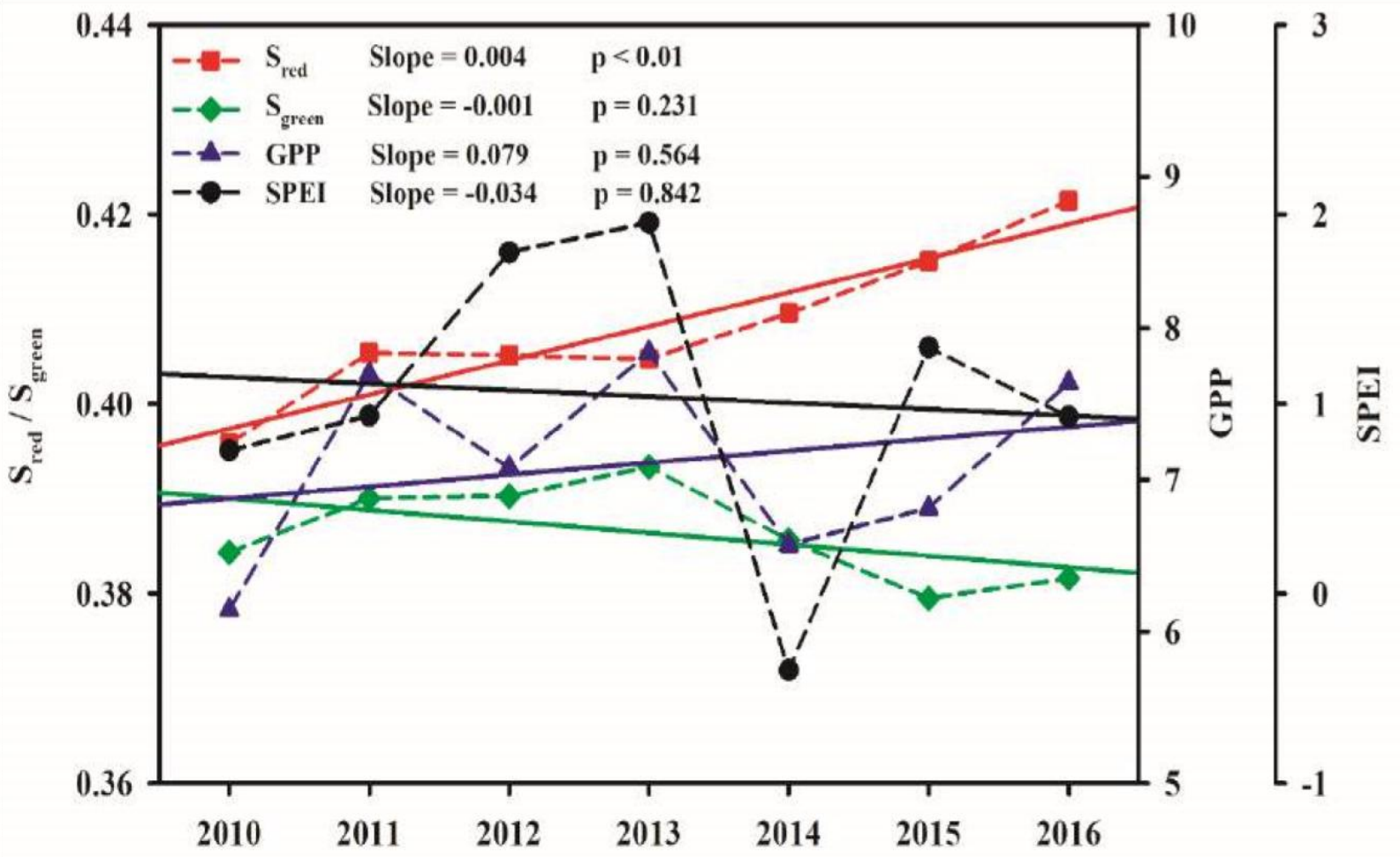

Day of year

Fig. 7. Annual variations in $S_{\text {red }}$, $S_{\text {green }}$, SPEI and GPP from 2010 to 2016.

The annual variation trends in colour indices $\left(S_{\text {red }}, S_{\text {green }}\right)$, GPP and drought index (SPEI) from 2010 to 2016 are shown in Fig. 7. There was an increasing trend of the $S_{\text {red }}$, with a significance $(p<0.01)$ of $0.004 / y r$, and the GPP, with an insignificance of $0.079 / y r$. There was a decreasing trend of the $S_{\text {green }}$ and the SPEI with $0.001 / \mathrm{yr}$ and 0.034/yr, respectively, and there was no significance (Fig. 6). The decreases in the SPEI and the GPP occurred in 2014 during the drought period (Fig. 7).

However, the $S_{\text {red }}$ continuously increased and the $S_{\text {green }}$ continuously decreased after the drought period, so the correlation between the SPEI and colour indices were still there after the drought. There was only a significant multiple linear relationship ( $\mathrm{p}<0.001)$ between the GPP with SPEI, total P and avg Ta throughout the year. Among the variables, the GPP was more significant ( $p$ $<0.001)$ with avg Ta. 


\section{International Journal of Current Science Research and Review}

ISSN: 2581-8341

Volume 04 Issue 10 October 2021

DOI: 10.47191/ijcsrr/V4-i10-20, Impact Factor: 5.825

IJCSRR@ 2021

WwW.ijesrr.org

\subsection{Annual relationship between colour indices, GPP with climatic factors and drought} index
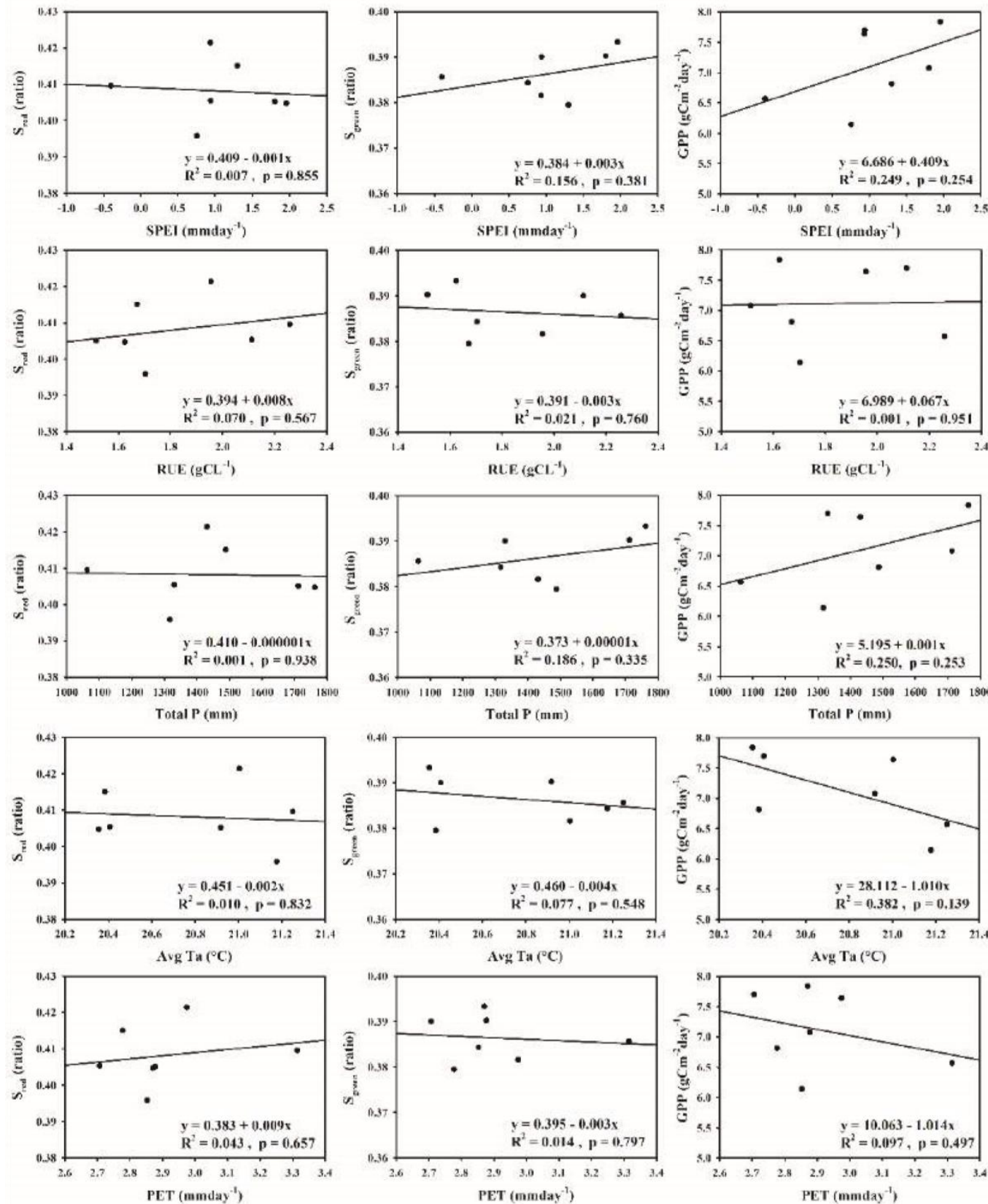

Fig. 8. Annual relationship between the average of the strength of red $\left(S_{\text {red }}\right)$, the strength of green $\left(S_{\text {green }}\right)$, the GPP and climatic factors (SPEI, RUE, total precipitation (Total P), average air temperature (Avg Ta) and PET) from 2010 to 2016.

A negative relationship was found between the $S_{\text {red }}$ and SPEI, but the $S_{\text {green }}$ had a positive relationship with the SPEI. Meanwhile, the $S_{\text {red }}$ had a positive relationship with RUE, and the $S_{\text {green }}$ had a negative relationship with it. However, the GPP had a positive relationship with the SPEI and RUE. The $S_{\text {red }}$ had an indirect relationship with total precipitation, but the $S_{\text {green }}$ and the GPP were directly correlated with the total precipitation. The $S_{\text {red }}$, $S_{\text {green }}$ and GPP had negative relationships with avg Ta and the PET, excepting the relationship of the $S_{\text {red }}$ with PET. There was no significant linear relationship between colour indices $\left(S_{\text {red }}\right.$ and $\left.S_{\text {green }}\right)$ and productivity with the climatic factors and drought index yearly (Fig. 8). 


\section{International Journal of Current Science Research and Review}

ISSN: 2581-8341

Volume 04 Issue 10 October 2021

DOI: 10.47191/ijcsrr/V4-i10-20, Impact Factor: 5.825

IJCSRR @ 2021

www.ijesrr.org

Among the climatic factors: avg Ta, total P, PET, SPEI and RUE, there was only correlation coefficient between the SPEI, RUE and total $\mathrm{P}$ with each other. There was only a significant multiple linear relationship between the GPP and SPEI, RUE and total P $\left(\mathrm{R}^{2}=0.976, \mathrm{p}<0.05\right)$.

However, there was no significant multiple linear relationship between the $S_{\text {red }}$ and $S_{\text {green }}$ with SPEI, RUE and total $P\left(R^{2}=0.431\right.$, $\mathrm{p}<0.814$ and $\left.\mathrm{R}^{2}=0.461, \mathrm{p}<0.788\right)$.

\section{DISCUSSION}

\subsection{Phenological observations}

The colour indices derived from the digital camera image showed the pattern of canopy phenology variations from year to year. The pattern of the colour indices was useful for determining the phenological variations of the forest cover (Nagai et al., 2016). In the results, the pattern of the $S_{\text {red }}$, the $S_{\text {green }}$ and the GEI showed phenological variations of the forest cover distinctly, but this was not found in the $S_{\text {blue }}$. However, the colour indices $\left(S_{\text {red }}\right.$ and $\left.S_{\text {green }}\right)$ were best for analysing the phenological variations of leaf senescence and leaf development (Zhao et al., 2012). The start of leaf colour variations pattern of the periods of the after drought was earlier than the periods of the before and during drought. The start of the leaf senescence (decline of the $S_{\text {red) }}$ and the green-up (increase of the $S_{\text {green }}$ ) were the same before and during the drought periods. After the drought, the green-up was DOY +9 days earlier than the start of leaf falls. The duration of the CVPs changed in our studied period. After the drought effect occurred, the CVPs was DOY +144 days longer than the previous. The peak GEI values were found at the end of the CVPs throughout the years. The drought effect enhanced the advancement of the growing season (Bernal et al., 2011). And also the drought caused the advance in CVPs and the beginnings of leaf colour variations before the drought periods were also earlier than in previous years. Therefore, there was the advance in green-up with longer CVP in rainforest due to drought effect.

The variations of the climate factors caused the change in pattern of colour indices and phenology variations. Temperature changes affected the date of the phenology variations (Dai et al., 2014; Güsewell et al., 2017), and high temperatures caused advances in leaf flushing (Vitasse et al., 2009). The yearly variations of mean air temperatures also affected the timing of phenology changes (Inoue et al., 2014; Nagai et al., 2013). The results showed the annual variations in climatic factors were correlated with the colour indices $S_{\text {red }}, S_{\text {green }}$ and GEI. However, the avg Ta was highest during the drought and continuously increased after the drought throughout the annual pattern. During the drought period, the climatic factors (total P, PET and avg Ta) were significant correlated with the $S_{\text {green }}$ and GEI. We also found the advanced in leaf emergence after the drought period with high temperature. Thus, the patterns of the rainforest's phenology variations were found after the drought period.

\subsection{Effects of drought on GPP}

The effect of drought enhanced not only the canopy phenology variations but also the productivity changes. Globally, droughts have huge and common effects on terrestrial carbon cycling (Frank et al., 2015). Droughts derive the reduction in the GPP by rainfall deficit and extreme heat (Ciais et al., 2005). Droughts affect the reduction in the GPP of the year 2014 with the lowest precipitation and highest average air temperature among the studied periods. The $S_{\text {red }}, S_{\text {green }}$, GEI and GPP were significantly correlated with the total P, PET and avg Ta throughout the CVP of the years. During the CVP of the drought, GPP was dropped and significantly correlated with PET and avg Ta.

The droughts enhanced the positive impacts on the GPP under favourable environmental conditions (Xu et al., 2019). Drought influenced the GPP but had no effect on RUE (Pereira et al., 2007). During the drought period, the GPP of the rainforest was the lowest and RUE was the highest among the studied periods. Plant phenology in response to drought can cause a reduction in productivity. Thus, the drought also directly affects rainforest productivity and negatively impacts the GPP under lower precipitation and higher temperature.

\subsection{The response of phenology and productivity to drought}

According to the pattern of the SPEI, there was a drought effect in the year of 2014. Although the effects of drought meant that the productivity of forest ecosystems was more sensitive to physiological than phenological changes (Zhang et al., 2016), the drought had a significant influence on leaf phenology and enhanced the advancement of flushing phenology (Čehulić et al., 2019). The leaf emergence date of the warmest period was earlier than normal among tree populations (Carter et al., 2017). The higher temperature forced plant development to speed up and caused the advanced green-up (Badeck et al., 2004; Gonçalves et al., 2020). The result showed there were no differences between the end of leaf fall and the start of leaf emergence before and during the 


\section{International Journal of Current Science Research and Review}

ISSN: 2581-8341

Volume 04 Issue 10 October 2021

DOI: 10.47191/ijcsrr/V4-i10-20, Impact Factor: 5.825

IJCSRR@ 2021

www.ijesrr.org

drought periods. Although the GPP was significant multiple linear relationship with SPEI, total P and avg Ta throughout the year, the avg Ta was highly significant with GPP. After the drought, the advancement in green-up and higher productivity were found in the rainforest with high temperature. Thus, the higher temperature was the main effect, and this caused the advancement in phenology variations and productivity in the rainforest. The vegetation index derived from satellites was correlated with the SPEI in the response of vegetation to drought (Gouveia et al., 2017; Vicente-Serrano et al., 2013; Zhang et al., 2017).

Thus, the SPEI is the best way to capture a drought's impacts on agricultural ecosystems

(Vicente-Serrano et al., 2012). The annual trend of the $S_{\text {red }}$ showed a significant increase from 2010 to 2016, but the GPP showed an increase and the $S_{\text {green }}$ and SPEI showed decrease trends with an insignificant relationship. RUE is directly related to climate warming (Yan et al., 2014) and indirectly related to rainfall (Gamoun, 2016). The results show that RUE and avg Ta were the highest and total $\mathrm{P}$ was the lowest during the drought period. Thus, RUE was directly proportional to avg Ta and indirectly proportional to total $P$. Our results show that the $S_{\text {red }}$ was negatively related to the SPEI and the $S_{\text {green }}$ was positively related to the SPEI at the annual scale. Meanwhile, the $S_{\text {red }}$ was positively related to the RUE and the $S_{\text {green }}$ was negatively related to the RUE at the annual scale. However, GPP was directly related with SPEI and indirectly related with RUE.

Drought affects deciduous forests, where trees drop their leaves early to reduce water loss and branch desiccation, and evergreen forests, where trees maintain their leaves to cause water loss and branch desiccation (Pollastrini et al., 2019). Deciduous tree species also preserve their apical buds and twigs to get new shoots and reform the canopy closure in later years (Pollastrini et al., 2019). In the rainforest study site, the start of the leaf CVP and the green-up after the drought periods was earlier than before drought periods. These conditions indicate that rainforests will drop their leaves early to lessen water loss and recover the forest canopy after drought periods.

The colour indices were correlated with the tower flux-based GPP (Ide et al., 2011; Sonnentag et al., 2011) and phenological changes were effected by productivity (Yu et al., 2018). The GPP was highly correlated with the colour indices (Toomey et al., 2015). There was a relationship between the GPP and the colour index derived from satellite observations during the drought period (Zhang et al., 2016). The GPP was respectively positively and negatively significantly related with the $S_{\text {red }}$ and $S_{\text {green }}$ before the drought. During and after the drought period, the GPP had a significant negative relationship with the $S_{\text {red }}$ and a significant positive relationship with the $S_{\text {green }}$. However, the GPP was significant relationship with the GEI during the drought period.

After the drought, the values of the rainforest's GPP was increasing with high temperature and precipitation. The advance in green-up and longer leaf CVPs may also be affected on the GPP. Thus, the drought enhanced the variation of the relationship between the GPP and the colour indices.

\section{CONCLUSION}

This study presents an investigation of the rainforest ecosystem response to drought through canopy phenology variations and productivity responses. Drought enhanced the advancement in leaf colour variations and the change in the pattern of the rainforest phenology variation in later years. Drought derived the advance in foliage green-up with the longer CVP on the later years. Drought directly affected and reduced the productivity of the rainforest and advanced in high productivity after the drought periods. The climatic factors were significantly related to the $S_{\text {red }}$ and the GPP during the CVP throughout the year. On the yearly time series, the colour indices and GPP also correlated with the climatic factors. The colour indices derived from the digital camera images and flux tower-based productivity could be used as factors for investigating the response of canopy phenology variations to drought in the rainforest. The effect of climate changes on the rainforest's canopy phenology and productivity can be assessed by analysing the variations of pattern of colour indices. Moreover, the effects of climatic factors on phenology variation and productivity in the rainforest ecosystem is complex and needs to be addressed over long-term durations.

\section{ACKNOWLEDGEMENTS}

This study was funded by CAS Key Laboratory of Tropical Forest Ecology, Xishuangbanna Tropical Botanical Garden, Chinese Academy of Sciences, Xishuangbanna, China; the National Natural Science Foundation of China (31770528, 41961144017); the National Key Research and Development Program of China (2016YFC0502105), and the Chinese Academy of Sciences 135 project (2017XTBG-T01; 2017XT BG-F01). This study was supported by the Xishuangbanna Station for Tropical Rainforest Ecosystem Studies (XSTRE). We would like to acknowledge the staff and technicians of Xishuangbanna Station and ChinaFlux . We thank colleagues in the Global Change Research Group, Xishuangbanna Tropical Botanical Garden (XTBG) for the collection 


\section{International Journal of Current Science Research and Review}

ISSN: 2581-8341

Volume 04 Issue 10 October 2021

DOI: 10.47191/ijesrr/V4-i10-20, Impact Factor: 5.825

of long-term data employed in this analysis. Finally, the first author deeply thanks the University of Chinese Academy of Sciences (UCAS) for the PhD scholarship and the Myanma Timber Enterprise of Myanmar for their encouragements.

\section{REFERENCES}

1. Ahrends, H.E., Brügger, R., Stöckli, R., Schenk, J., Michna, P., Jeanneret, F., Wanner, H., Eugster, W., 2008. Quantitative phenological observations of a mixed beech forest in northern Switzerland with digital photography. J. Geophys. Res. Biogeosciences 113, 1-11. https://doi.org/10.1029/2007JG000650

2. Alberton, B., Torres, S., Cancian, L.F., Borges, B.D., Almeida, J., Mariano, G.C., Patricia, L., Morellato, C., 2017. Introducing digital cameras to monitor plant phenology in the tropics : applications for conservation. Perspect. Ecol. Conserv. 15, 82-90. https://doi.org/10.1016/j.pecon.2017.06.004

3. Anderson, L.O., Malhi, Y., Aragão, L.E.O.C., Ladle, R., Arai, E., Barbier, N., Phillips, O., 2010.

4. Remote sensing detection of droughts in Amazonian forest canopies. New Phytol. 187, 733-750. https://doi.org/10.1111/j.1469-8137.2010.03355.x

5. Badeck, F.W., Bondeau, A., Böttcher, K., Doktor, D., Lucht, W., Schaber, J., Sitch, S., 2004.

6. Responses of spring phenology to climate change. New Phytol. 162, 295-309. https://doi.org/10.1111/j.14698137.2004.01059.x

7. Bernal, M., Estiarte, M., Peñuelas, J., 2011. Drought advances spring growth phenology of the Mediterranean shrub Erica multiflora. Plant Biol. 13, 252-257. https://doi.org/10.1111/j.1438-8677.2010.00358.x

8. Bogdziewicz, M., Fernández- Martínez, M., Espelta, J.M., Ogaya, R., Penuelas, J., 2020. Is forest fecundity resistant to drought? Results from an 18- year rainfall- reduction experiment. New Phytol. https://doi.org/10.1111/nph.16597

9. Cao, Z., Li, Y., Liu, Y., Chen, Y., Wang, Y., 2018. When and where did the Loess Plateau turn "green"? Analysis of the tendency and breakpoints of the normalized difference vegetation index. L. Degrad. Dev. 29, $162-175$. https://doi.org/10.1002/ldr.2852

10. Carter, J.M., Orive, M.E., Gerhart, L.M., Stern, J.H., Marchin, R.M., Nagel, J., Ward, J.K., 2017.

11. Warmest extreme year in U.S. history alters thermal requirements for tree phenology. Oecologia 183, 1197-1210. https://doi.org/10.1007/s00442-017-3838-z

12. Caudullo, G., Barredo, J.I., 2019. A georeferenced dataset of drought and heat-induced tree mortality in Europe. One Ecosyst. 4. https://doi.org/10.3897/oneeco.4.e37753

13. Čehulić, I., Sever, K., Bogdan, I.K., Jazbec, A., Škvorc, Ž., Bogdan, S., 2019. Drought impact on leaf phenology and spring frost susceptibility in a Quercus robur L. provenance trial. Forests 10. https://doi.org/10.3390/f10010050

14. Ciais, P., Reichstein, M., Viovy, N., Granier, A., Ogée, J., Allard, V., Aubinet, M., Buchmann, N., Bernhofer, C., Carrara, A., Chevallier, F., De Noblet, N., Friend, A.D., Friedlingstein, P., Grünwald, T., Heinesch, B., Keronen, P., Knohl, A., Krinner, G., Loustau, D., Manca, G., Matteucci, G., Miglietta, F., Ourcival, J.M., Papale, D., Pilegaard, K., Rambal, S., Seufert, G., Soussana, J.F., Sanz, M.J., Schulze, E.D., Vesala, T., Valentini, R., 2005.

15. Europe-wide reduction in primary productivity caused by the heat and drought in 2003. Nature 437, 529-533. https://doi.org/10.1038/nature03972

16. Copeland, S.M., HarrISon, S. p., LatIMer, andrew M., DaMScHen, ellen I., ESkelInen, anu M., Fernandez-GoInG, B., SpaSoJevIc, M.J., Anacker, B. 1., THorne, J.H., 2016. Ecological effects of extreme drought on Californian herbaceous plant communities. Ecol. Monogr. 86, 295-311.

17. Dahlin, K.M., Ponte, D. Del, Setlock, E., Nagelkirk, R., 2017. Global patterns of drought deciduous phenology in semiarid and savanna-type ecosystems. Ecography (Cop.). 40, 314-323. https://doi.org/10.1111/ecog.02443

18. Dai, A., 2013. Increasing drought under global warming in observations and models. Nat. Clim. Chang. 3, 52-58. https://doi.org/10.1038/nclimate1633

19. Dai, J., Wang, H., Ge, Q., 2014. The spatial pattern of leaf phenology and its response to climate change in China. Int. J. Biometeorol. 58, 521-528. https://doi.org/10.1007/s00484-013-0679-2

20. Fei, X., Song, Q., Zhang, Y., Liu, Y., Sha, L., Yu, G., Zhang, L., Duan, C., Deng, Y., Wu, C., Lu, Z., Luo, K., Chen, A., Xu, K., Liu, W., Huang, H., Jin, Y., Zhou, R., Li, J., Lin, Y., 


\section{International Journal of Current Science Research and Review}

ISSN: 2581-8341

Volume 04 Issue 10 October 2021

DOI: 10.47191/ijesrr/V4-i10-20, Impact Factor: 5.825

21. Zhou, L., Fu, Y., Bai, X., Tang, X., Gao, J., Zhou, W., Grace, J., 2018. Carbon exchanges and their responses to temperature and precipitation in forest ecosystems in Yunnan, Southwest China. Sci. Total Environ. 616-617, 824-840. https://doi.org/10.1016/j.scitotenv.2017.10.239

22. Fensham, R.J., Laffineur, B., Allen, C.D., 2019. To what extent is drought-induced tree mortality a natural phenomenon? Glob. Ecol. Biogeogr. 28, 365-373. https://doi.org/10.1111/geb.12858

23. Frank, Dorothea, Reichstein, M., Bahn, M., Thonicke, K., Frank, David, Mahecha, M.D., Smith, P., van der Velde, M., Vicca, S., Babst, F., Beer, C., Buchmann, N., Canadell, J.G., Ciais,

24. P., Cramer, W., Ibrom, A., Miglietta, F., Poulter, B., Rammig, A., Seneviratne, S.I., Walz, A., Wattenbach, M., Zavala, M.A., Zscheischler, J., 2015. Effects of climate extremes on the terrestrial carbon cycle: Concepts, processes and potential future impacts. Glob. Chang. Biol. 21, 2861-2880. https://doi.org/10.1111/gcb.12916

25. Gamoun, M., 2016. Rain Use Efficiency, Primary Production and Rainfall Relationships in Desert Rangelands of Tunisia. L. Degrad. Dev. 27, 738-747. https://doi.org/10.1002/ldr.2418

26. George H. Hargreaves, Zohrab A. Samani, 1985. Reference Crop Evapotranspiration from Temperature. Appl. Eng. Agric. 1, 96-99. https://doi.org/10.13031/2013.26773

27. Gillespie, A.R., Kahle, A.B., Walker, R.E., 1987. Color enhancement of highly correlated images. II. Channel ratio and "chromaticity" transformation techniques. Remote Sens. Environ. 22, 343-365. https://doi.org/10.1016/0034-4257(87)90088-5

28. Gilmanov, T.G., Soussana, J.F., Aires, L., Allard, V., Ammann, C., Balzarolo, M., Barcza, Z., Bernhofer, C., Campbell, C.L., Cernusca, A., Cescatti, A., Clifton-Brown, J., Dirks, B.O.M., Dore, S., Eugster, W., Fuhrer, J., Gimeno, C., Gruenwald, T., Haszpra, L., Hensen, A., Ibrom, A., Jacobs, A.F.G., Jones, M.B., Lanigan, G., Laurila, T., Lohila, A., G.Manca, Marcolla, B., Nagy, Z., Pilegaard, K., Pinter, K., Pio, C., Raschi, A., Rogiers, N., Sanz,

29. M.J., Stefani, P., Sutton, M., Tuba, Z., Valentini, R., Williams, M.L., Wohlfahrt, G., 2007. Partitioning European grassland net ecosystem $\mathrm{CO} 2$ exchange into gross primary productivity and ecosystem respiration using light response function analysis. Agric. Ecosyst. Environ. 121, 93-120. https://doi.org/10.1016/j.agee.2006.12.008

30. Gonçalves, N.B., Lopes, A.P., Dalagnol, R., Wu, J., Pinho, D.M., Nelson, B.W., 2020. Both near-surface and satellite remote sensing confirm drought legacy effect on tropical forest leaf phenology after 2015/2016 ENSO drought. Remote Sens. Environ. 237, 111489. https://doi.org/10.1016/j.rse.2019.111489

31. Gouveia, C.M., Trigo, R.M., Beguería, S., Vicente-Serrano, S.M., 2017. Drought impacts on vegetation activity in the Mediterranean region: An assessment using remote sensing data and multi-scale drought indicators. Glob. Planet. Change 151, 15-27. https://doi.org/10.1016/j.gloplacha.2016.06.011

32. Güsewell, S., Furrer, R., Gehrig, R., Pietragalla, B., 2017. Changes in temperature sensitivity of spring phenology with recent climate warming in Switzerland are related to shifts of the preseason. Glob. Chang. Biol. 23, 5189-5202. https://doi.org/10.1111/gcb.13781

33. Hollinger, D.Y., Kelliher, F.M., Byers, J.N., Hunt, J.E., McSeveny, T.M., Weir, P.L., 1994. Carbon dioxide exchange between an undisturbed old-growth temperate forest and the atmosphere. Ecology 75, 134-150. https://doi.org/10.2307/1939390

34. Huang, F., Wang, P., Chang, S., Li, B., 2018. Rain use efficiency changes and its effects on land surface phenology in the Songnen Plain, Northeast China 16. https://doi.org/10.1117/12.2325086

35. Huxman, T.E., Smith, M.D., Fay, P.A., Knapp, A.K., Shaw, M.R., Lolk, M.E., Smith, S.D., Tissue, D.T., Zak, J.C., Weltzin, J.F., Pockman, W.T., Sala, O.E., Haddad, B.M., Harte, J., Koch, G.W., Schwinning, S., Small, E.E., Williams, D.G., 2004. Convergence across biomes to a common rain-use efficiency. Nature 429, 651-654. https://doi.org/10.1038/nature02561

36. Ide, R., Nakaji, T., Motohka, T., Oguma, H., 2011. Advantages of visible-band spectral remote sensing at both satellite and near-surface scales for monitoring the seasonal dynamics of GPP in a Japanese larch forest. J. Agric. Meteorol 67 (2), 75-84. https://doi.org/10.2480/agrmet.67.2.4

37. Inoue, T., Nagai, S., Saitoh, T.M., Muraoka, H., Nasahara, K.N., Koizumi, H., 2014. Detection of the different characteristics of year-to-year variation in foliage phenology among deciduous broad-leaved tree species by using daily continuous canopy surface images. Ecol. Inform. 22, 58-68. https://doi.org/10.1016/j.ecoinf.2014.05.009 


\section{International Journal of Current Science Research and Review}

ISSN: 2581-8341

Volume 04 Issue 10 October 2021

DOI: 10.47191/ijcsrr/V4-i10-20, Impact Factor: 5.825

38. Lauenroth, W.K., Burke, I.C., Paruelo, J.M., 2000. Patterns of production and precipitation-use efficiency of winter wheat and native grasslands in the central Great Plains of the United States. Ecosystems 3, 344-351. https://doi.org/10.1007/s100210000031

39. Li, H., Aide, T.M., Ma, Y., Liu, W., Cao, M., 2007. Demand for rubber is causing the loss of high diversity rain forest in SW China. Biodivers. Conserv. 16, 1731-1745. https://doi.org/10.1007/s10531-006-9052-7

40. Li, M.Y., Fang, L.D., Duan, C.Y., Cao, Y., Yin, H., Ning, Q.R., Hao, G.Y., 2020. Greater risk of hydraulic failure due to increased drought threatens pine plantations in Horqin Sandy Land of northern China. For. Ecol. Manage. 461. https://doi.org/10.1016/j.foreco.2020.117980

41. Liu, D., Zhang, C., Ogaya, R., Estiarte, M., Peñuelas, J., 2020. Effects of decadal experimental drought and climate extremes on vegetation growth in Mediterranean forests and shrublands. J. Veg. Sci. 13, jvs.12902. https://doi.org/10.1111/jvs.12902

42. McKee, T.B., Doesken, N.J., Kleist, J., 1993. The relationship of drought frequency and duration to time scales. Eighth Conf. Appl. Clim. Anaheim, 179-184.

43. Myo, S.T.Z., Zhang, Y., Song, Q.H., Deng, Y., Fei, X., Zhou, R., Lin, Y., Zhou, L., Zhang, P., 2019. Analysis of canopy temperature depression between tropical rainforest and rubber plantation in Southwest China. IForest 12, 518-526. https://doi.org/10.3832/ifor3101-012

44. Nagai, S., Ichie, T., Yoneyama, A., Kobayashi, H., Inoue, T., Ishii, R., Suzuki, R., Itioka, T., 2016. Usability of timelapse digital camera images to detect characteristics of tree phenology in a tropical rainforest. Ecol. Inform. 32, 91-106. https://doi.org/10.1016/j.ecoinf.2016.01.006

45. Nagai, S., Saitoh, T.M., Kurumado, K., Tamagawa, I., Kobayashi, H., Inoue, T., Suzuki, R., Gamo, M., Muraoka, H., Nishida Nasahara, K., 2013. Detection of Bio-Meteorological Year-to-Year Variation by Using Digital Canopy Surface Images of a Deciduous Broad-Leaved Forest. SOLA 9, 106-110. https://doi.org/10.2151/sola.2013-024

46. Ogaya, R., Liu, D., Barbeta, A., Peñuelas, J., 2020. Stem Mortality and Forest Dieback in a 20Years Experimental Drought in a Mediterranean Holm Oak Forest. Front. For. Glob. Chang. 2, 1-9. https://doi.org/10.3389/ffgc.2019.00089

47. Onyewotu, L.O.Z., Stigter, C.J., Oladipo, E.O., Owonubi, J.J., 1998. Yields of millet between shelterbelts in semi-arid northern Nigeria, with a traditional and a scientific method of determining sowing date, and at two levels of organic manuring. Netherlands J. Agric. Sci. 46, 53-64.

48. Palmer, W.C., 1965. Meteorological drought. Pereira, J.S., Mateus, J.A., Aires, L.M., Pita, G., Pio, C., David, J.S., Andrade, V., Banza, J., David, T.S., Paço, T.A., Rodrigues, A., 2007. Net ecosystem carbon exchange in three contrasting Mediterranean ecosystems - The effect of drought. Biogeosciences 4, 791-802. https://doi.org/10.5194/bg-4-791-2007

49. Pollastrini, M., Puletti, N., Selvi, F., Iacopetti, G., Bussotti, F., 2019. Widespread Crown Defoliation After a Drought and Heat Wave in the Forests of Tuscany (Central Italy) and Their Recovery-A Case Study From Summer 2017. Front. For. Glob. Chang. 2, 1-8. https://doi.org/10.3389/ffgc.2019.00074

50. Prevéy, J., Vellend, M., Rüger, N., Hollister, R.D., Bjorkman, A.D., Myers-Smith, I.H., Elmendorf, S.C., Clark, K., Cooper, E.J., Elberling, B., Fosaa, A.M., Henry, G.H.R., Høye, T.T., Jónsdóttir, I.S., Klanderud, K., Lévesque, E., Mauritz, M., Molau, U., Natali, S.M.,

51. Oberbauer, S.F., Panchen, Z.A., Post, E., Rumpf, S.B., Schmidt, N.M., Schuur, E.A.G., Semenchuk, P.R., Troxler, T., Welker, J.M., Rixen, C., 2017. Greater temperature sensitivity of plant phenology at colder sites: implications for convergence across northern latitudes. Glob. Chang. Biol. 23, 2660-2671. https://doi.org/10.1111/gcb.13619

52. Saatchi, S., Asefi-Najafabady, S., Malhi, Y., Aragão, L.E.O.C., Anderson, L.O., Myneni, R.B., Nemani, R., 2013. Persistent effects of a severe drought on Amazonian forest canopy. Proc. Natl. Acad. Sci. U. S. A. 110, 565-570. https://doi.org/10.1073/pnas.1204651110

53. Salinger, M.J., Stigter, C.J., Das, H.P., 2000. Agrometeorological adaptation strategies to increasing climate variability and climate change. Agric. For. Meteorol. 103, 167-184.

54. Sonnentag, O., Detto, M., Vargas, R., Ryu, Y., Runkle, B.R.K., Kelly, M., Baldocchi, D.D., 2011. Tracking the structural and functional development of a perennial pepperweed 


\section{International Journal of Current Science Research and Review}

ISSN: 2581-8341

Volume 04 Issue 10 October 2021

DOI: 10.47191/ijcsrr/V4-i10-20, Impact Factor: 5.825

55. (Lepidium latifolium L.) infestation using a multi-year archive of webcam imagery and eddy covariance measurements. Agric. For. Meteorol. 151, 916-926. https://doi.org/10.1016/j.agrformet.2011.02.011

56. Sonnentag, O., Hufkens, K., Teshera-sterne, C., Young, A.M., Friedl, M., Braswell, B.H., Milliman, T., Keefe, J.O., Richardson, A.D., 2012. Digital repeat photography for phenological research in forest ecosystems. Agric. For. Meteorol. 152, 159-177. https://doi.org/10.1016/j.agrformet.2011.09.009

57. Stovall, A.E.L., Shugart, H., Yang, X., 2019. Tree height explains mortality risk during an intense drought. Nat. Commun. 10. https://doi.org/10.1038/s41467-019-12380-6

58. Toomey, M., Friedl, M.A., Frolking, S., Hufkens, K., Klosterman, S., Sonnentag, O., Baldocchi, D.D., Bernacchi, C.J., Biraud, S.C., Bohrer, G., Brzostek, E., Burns, S.P., Coursolle, C.,

59. Hollinger, D.Y., Margolis, H.A., Mccaughey, H., Monson, R.K., Munger, J.W., Pallardy, S., Phillips, R.P., Torn, M.S., Wharton, S., Zeri, M., Richardson, A.D., 2015. Greenness indices from digital cameras predict the timing and seasonal dynamics of canopy-scale photosynthesis. Ecol. Appl. 25, 99-115.

60. Vicente-Serrano, S.M., Beguería, S., López-Moreno, J.I., 2010. A Multiscalar Drought Index Sensitive to Global Warming: The Standardized Precipitation Evapotranspiration Index. J. Clim. 23, 1696-1718.

https://doi.org/10.1175/2009JCLI2909.1

61. Vicente-Serrano, S.M., Beguería, S., Lorenzo-Lacruz, J., Camarero, J.J., López-Moreno, J.I., Azorin-Molina, C., Revuelto, J., Morán-Tejeda, E., Sanchez-Lorenzo, A., 2012. Performance of drought indices for ecological, agricultural, and hydrological applications. Earth Interact. 16. https://doi.org/10.1175/2012EI000434.1

62. Vicente-Serrano, S.M., Gouveia, C., Camarero, J.J., Beguería, S., Trigo, R., López-Moreno, J.I., Azorín-Molina, C., Pasho, E., Lorenzo-Lacruz, J., Revuelto, J., Morán-Tejeda, E., SanchezLorenzo, A., 2013. Response of vegetation to drought time-scales across global land biomes. Proc. Natl. Acad. Sci. U. S. A. 110, 52-57.

https://doi.org/10.1073/pnas.1207068110

63. Vitasse, Y., Porté, A.J., Kremer, A., Michalet, R., Delzon, S., 2009. Responses of Canopy Duration to Temperature Changes in Four Temperate Tree Species_Relative Contributions of Spring and Autumn Leaf Phenology. Oecologia 161, 187-198. https://doi.org/110.1007/s00442-009- 1363-4

64. Westergaard-Nielsen, A., Lund, M., Hansen, B.U., Tamstorf, M.P., 2013. Camera derived vegetation greenness index as proxy for gross primary production in a low Arctic wetland area. ISPRS J. Photogramm. Remote Sens. 86, 89-99. https://doi.org/10.1016/j.isprsjprs.2013.09.006

65. Woebbecke, D.M., Meyer, G.E., Bargen, K. Von, Mortensen, D.A., 1995. Color Indices for Weed Identification Under Various Soil, Residue, and Lighting Conditions. Trans. ASAE 38, 259-269. https://doi.org/10.13031/2013.27838

66. Xu, C., McDowell, N.G., Fisher, R.A., Wei, L., Sevanto, S., Christoffersen, B.O., Weng, E., Middleton, R.S., 2019. Increasing impacts of extreme droughts on vegetation productivity under climate change. Nat. Clim. Chang. 9, 948-953. https://doi.org/10.1038/s41558-019-0630-6

67. Yan, L., Luo, Y., Sherry, R.A., Bell, J.E., Zhou, X., Xia, J., 2014. Rain use efficiency as affected by climate warming and biofuel harvest: Results from a 12-year field experiment. GCB Bioenergy 6, 556-565. https://doi.org/10.1111/gcbb.12081

68. Yu, R., Schwartz, M.D., Donnelly, A., Liang, L., 2015. An observation-based progression modeling approach to spring and autumn deciduous tree phenology. Int. J. Biometeorol. 335-349. https://doi.org/10.1007/s00484-015-1031-9

69. Yu, Z., Lu, C., Cao, P., Tian, H., Hessl, A., Pederson, N., 2018. Earlier leaf-flushing suppressed ecosystem productivity by draining soil water in the Mongolian Plateau. Agric. For. Meteorol. 250-251, 1-8.

https://doi.org/10.1016/j.agrformet.2017.11.035

70. Zahir, A., Abbasi, B.H., Adil, M., Anjum, S., Zia, M., Ihsan-Ul-Haq, 2014. Synergistic effects of drought stress and photoperiods on phenology and secondary metabolism of Silybum marianum. Appl. Biochem. Biotechnol. 174, 693-707. https://doi.org/10.1007/s12010-0141098-5

71. Zhang, Q., Kong, D., Singh, V.P., Shi, P., 2017. Response of vegetation to different time-scales drought across China: Spatiotemporal patterns, causes and implications. Glob. Planet. Change 152, 1-11.

https://doi.org/10.1016/j.gloplacha.2017.02.008 


\section{International Journal of Current Science Research and Review}

ISSN: 2581-8341

Volume 04 Issue 10 October 2021

DOI: 10.47191/ijesrr/V4-i10-20, Impact Factor: 5.825

IJCSRR @ 2021

Www.ijcsrr.org

72. Zhang, Y., Xiao, X., Zhou, S., Ciais, P., McCarthy, H., Luo, Y., 2016. Canopy and physiological controls of GPP during drought and heat wave. Geophys. Res. Lett. 43, 3325-3333. https://doi.org/10.1002/2016GL068501

73. Zhao, A., Zhang, A., Liu, J., Feng, L., Zhao, Y., 2019. Assessing the effects of drought and "Grain for Green” Program on vegetation dynamics in China's Loess Plateau from 2000 to 2014. Catena 175, 446-455.

https://doi.org/10.1016/j.catena.2019.01.013

74. Zhao, A., Zhanga, A., Caoc, S., Liud, X., Liue, J., Chenga, D., 2018. Responses of vegetation productivity to multi-scale drought in Loess Plateau, China. Catena 163, 165-171. https://doi.org/10.1016/j.catena.2017.12.016

75. Zhao, Junbin, Zhang, Y., Tan, Z., Song, Q., Liang, N., Yu, L., Zhao, Junfu, 2012. Using digital cameras for comparative phenological monitoring in an evergreen broad-leaved forest and a seasonal rain forest. Ecol. Inform. 10, 65-72. https://doi.org/10.1016/j.ecoinf.2012.03.001

76. Zhao, Y., Wang, X., Vázquez-Jiménez, R., 2018. Evaluating the performance of remote sensed rain-use efficiency as an indicator of ecosystem functioning in semi-arid ecosystems. Int. J. Remote Sens. 39, 3344-3362. https://doi.org/10.1080/01431161.2018.1439598

77. Zhou, R., Zhang, Y., Song, Q., Lin, Y., Sha, L., Jin, Y., 2019. Relationship between gross primary production and canopy colour indices from digital camera images in a rubber (Hevea brasiliensis ) plantation, Southwest China Forest Ecology and Management Relationship between gross primary production and canopy colou. For. Ecol. Manage. 437, 222-231. https://doi.org/10.1016/j.foreco.2019.01.019

Cite this Article: Sai Tay Zar Myo, Yiping Zhang, Qinghai Song, Xuehai Fei, Donghai Yang, Zayar Phyo (2021). Investigating the Rainforest Canopy Phenology Variation and Productivity Responses to Drought by Using Digital Camera Images. International Journal of Current Science Research and Review, 4(10), 1378-1397 